\title{
Foreign Trade and Economic Growth in Iran: An Empirical Study
}

\author{
Seyed Mohammad Alavinasab, Ph.D. \\ Faculty of Management, University of Tehran, Farabi College, Iran \\ Email: alavinsb@ut.ac.ir
}

DOI: $\quad$ 10.6007/IJARBSS/v3-i11/369 URL: http://dx.doi.org/10.6007/IJARBSS/v3-i11/369

\begin{abstract}
This study examines the impact of foreign trade on economic growth in Iran. Using time series data, a regression analysis was carried out using E. Views statistical software. Results showed that non-oil exports, industrial and agricultural value added positively impacted on economic growth. Imports had a negative impact on growth, while exchange rate was wrongly signed.

Keywords: Non-oil exports, Imports, Exchange rate, Economic growth, Iran.

\section{Introduction}

Foreign trade is considered as an essential factor for accelerating the path of economic growth. Most countries are involved into foreign trade to create employment, raise propensity to save, increase foreign exchange earnings, and raise the productivity of investment moving from less productive use to high productive use. Foreign trade has been regarded as an engine of growth, lead to steady improvement in human status by expanding the range of people's standard and preference. Since no country has grown without trade, foreign trade plays a vital role in restructuring economic and social attributes of countries around the world. Experience of economies suggesting that countries which are active at the international exchanges tend to be more productive compared to the countries that produce only for the domestic market. Hence, considering above, a study on the effects of foreign trade on economic growth seems to be essential. Such a study can help to economic policy makers to determine the sources of growth and with regard to international trade, adopt appropriate policies.
\end{abstract}

The volume and value of foreign trade particularly in developing countries during the past few decades have been increased. Iran's foreign trade statistics indicate that non-oil exports was valued 22.56 billion dollars in 2010, while imports reached to 68.45 billion dollars and total export was valued $\mathbf{1 0 8 . 6}$ billion dollars in the same year. Although, the general trend of Iran's foreign trend (excluding oil exports) has been growing trend but cited statistics show that Iranian economy is highly dependent on oil revenues and non-oil exports value have not optimum share in meeting import value, so that the trade deficit includes -45.89 billion dollars in 2010. This is expected that Iran's economy by applying appropriate policies on trade liberalization in order to achieve economic growth, can improve economic conditions. 
Also, considering the differences in theoretical discussions and empirical findings about the impact of foreign trade on economic growth, especially in developing countries, further investigation is required. This study can contribute to the debate, using Iran as a case study.

Therefore, the objective of present study is to investigate the impact of foreign trade on economic growth in Iran for the period 1961-2010. Specifically, the study aims to see the effects of Non-oil exports, Imports, exchange rate and industrial and agricultural value added on economic growth of Iran. The rest of this paper is organized as follows: Review of literature is presented in section II. Methodology and data will be discussed in section III. Estimation results and the conclusion are presented in sections IV and V, respectively.

\section{Literature Review}

There has been increasing interest in the study of foreign trade and its benefits particularly to developing countries. The effect of foreign trade on economic growth, empirically, has been an important and controversial subject for several decades. A number of studies, using different approaches, have found growth to be enhanced by trade openness, or liberalization (Krueger, 1978; Feder, 1983; Ram, 1985 and 1987; Balassa, 1978 and 1985; Dollar, 1992; Edwards, 1998; Ben-David et al., 2000; among others). On the other hand, some studies like Singer (1950), Prehisch (1962), Kavoussi (1985), Singer and Gray (1988), Sachs (1987 and 1989) and Taylor (1991) have argued that trade or trade expansion may not be beneficial for the economic growth of all countries at all times. Goldberg and Pavcnik (2007) investigate the relationship between trade and income growth in developing countries and conclude that globalization benefits are country, time, and case specific. Rodriguez and Rodrik (2001) analyze the relationship between trade policies, trade volume, and output growth and find no substantial evidence to suggest trade increases economic growth. In fact, the conclusions in past literature regarding empirical benefits from international trade are mixed.

Some of empirical studies on the relationship between export and economic growths have found export growth to be associated with increase in output or GDP (Michaely, 1977; Tyler, 1981 and Balassa(1985). Michaely (1977) used simple regression and correlation analysis to investigate the relationship between exports and growth. They found that in less developed countries, there was a weak correlation. They, however, raised an important issue to determine the minimum level of development a country has to attain in order to benefit from trade.

Jiles and Williams (2000) note that not all authors support export-led growth theory because of the vast empirical differences between the growth in the East and Southeast Asian countries and Latin America. Panas and Vamvoukas (2002) showed that the export led growth is not valid in the case of Greece and findings suggest a strong and consistent causation from output growth to export performance in long run.

Frankel and Romer (1999) found significant impact of trade openness on level of per capita income. They argued that trade possibilities enhance growth through greater capital stock, stock of education and higher total factor productivity. They, however, warned explicitly against drawing inferences for trade policies based on their results as it brings different factors into play. However, the empirical analysis of the relationship between trade openness and economic growth has generated mixed results. 
Some studies also argued that foreign trade impacts the economic growth of countries through the attraction of foreign direct investment (FDI). According to Lall (2000) and Te Velde (2001), the main channels through which FDI contributes to economic growth are technology transfer, capital accumulation, access to international market, job creation and managerial and marketing practices; and Blomstrom and Kokko (2003) added that trade and FDI can only facilitate growth after the minimum level of human capital, infrastructure and technology have been met.

Kruger (1983) states that decrease in imports of capital goods declines the GDP growth rate and in contrast, decrease in import of raw materials and intermediate goods, has positive impact on production and employment. Mohsen Khan and Rynhart (1990) showed that in addition to exports, import of intermediate and capital goods, also had positive significant impact on economic growth for 24 developing countries.

Coe and Helpman (1995) using time-series data show that trade affect economic growth positively through technological transfer. Similarly, Bayoumi et al. (1999) assert that research and development, its spillover and trade play important roles in promoting economic growth both in industrial and developing countries. Levine and Renelt (1992) and Wacziarg (2001) showed that international trade influences growth through investment (factor accumulation). Frankel and Romer (1999) specifically found trade to influence growth through human capital accumulation. Also, some authors had examined the performance of foreign trade on economic growth in Iran, including: Komijani and Memarnejad (2004) examined the impact of quality manpower and R \& D on economic growth. Results show that labor force, human capital, physical capital and oil earnings have positive significant impact on economic growth, while impact of inflation is negative and insignificant. Khataie and Gharbali Moghaddam (2005) examined the dynamic relationship between foreign exchange rate and GDP. Results show that there is a negative though weak relation between real foreign exchange rate and GDP, and also, increase in nominal exchange rate, has a weak negative impact on GDP growth. Pahlavani (2005) examined the relationship between trade and economic growth in Iran from 1960 to 2003. Results obtained by the Saikkonen and Lutkephol co-integration approach indicate that there is one co-integrating vector which links GDP with physical and human capital, imports and exports. These co-integration test results also remain robust despite disaggregating exports into the two categories of oil and non-oil exports. Mahdavi and Javadi (2006) investigation on causal relationship between foreign trade and economic growth show that the positive influence of foreign trade on economic growth, itself being the result of positive impact of import increases on total value added of manufacturing, mineral, and agricultural sectors and the positive impact of oil export increases on the value added of service sector. Mahdavi and Fatemi (2007) investigated the impact of non- oil Exports on economic growth. Results show too weak impact on gross domestic product growth of non - oil exports and also low factor productivity in export sector relative to non - export sector. Taghavi et al. (2012) showed that, export has direct and positive relationship with economic growth in long run and import has a negative significant relationship with economic growth, while effect of import on economic growth is negative in long-term. Mirjamali Mehrabadi et al. (2012) examined the effects of oil and non-oil export on economic growth. Results show that oil and non-oil exports, both of the variables have positive effect on the economic growth of Iran. 


\section{Methodology and Data}

\section{Data}

This study is based on secondary data ranging from 1961 to 2010 . They include the annual series data on: gross domestic product, non-oil exports, imports, exchange rate, gross fixed capital formation, industrial value added and agricultural value added. Data on all variables have been extracted from the Time Series Database of Central Bank of Iran and internet sites. The variables of gross domestic product, imports, gross fixed capital formation, industrial value added and agriculture value added measured at constant price $(1997=100)$.

\section{Estimation Procedure}

The study involves quantitative analysis of the variables used in this research, adopting the method of Ordinary Least Squares (OLS) econometric statistical technique as an analytical technique. In addition, for time series data analysis Augmented Dickey Fuller (ADF) test and Johansen co-integration test have been used. Also, E. Views statistical software has been used for results derivation.

\section{Econometric model}

In present study an attempt has been made to investigate the impact of trade on economic growth in Iran. This model derives from the earlier studies by Panas and Vamvoukas (2002), Pahlavani (2005) and Mahdavi and Javadi (2006) though with some modifications. The dependent variable in the model is economic growth which is measured by Gross Domestic Product. While the explanatory variables include non-oil export value, import value, gross capital formation, exchange rate, industrial value added and agricultural value added. Hence, the study specifies the growth function as follows:

$G D P=f(N O X, M, K, I V A, A V A, E X R, D U M)$

Where

$\mathrm{GDP}=$ gross domestic product, $\mathrm{NOX}=$ non-oil export value, $\mathrm{M}=$ import value $\mathrm{K}=$ gross capital formation, IVA = industrial value added, AVA = agricultural value added, EXR = exchange rate, DUM = Dummy variable for years 1980-1987 (war years).

The model expressed in the form of the log linear regression as follows:

$\log G D P=b_{0}+b_{1} \log N O X+b_{2} \log M+b_{3} \log K+b_{4} \log I V A+b_{5} \log A V A+b_{6} \log E X R+b_{7} D U M+\mu$

The expected signs of the coefficient of the explanatory variables are:

$$
b_{1}, b_{3}, b_{4}, b_{5}, b_{6}>0 ; b_{2}, b_{7}<0
$$

\section{Empirical Results}

First, the Augmented Dickey-Fuller (ADF) unit root test was applied to the logarithms of the time series employed in the study with and without time trend. Table 1 represents the null hypothesis that the series are non-stationary is not rejected at the levels of variables. Therefore, it is concluded that the GDP, NOX, M, IVA, AVA, K and EXR are non-stationary series. 
Table 1. ADF Unit Root Test: level series

\begin{tabular}{|c|c|c|c|c|}
\hline \multirow[t]{2}{*}{ Variable } & \multicolumn{2}{|c|}{$5 \%$ critical value } & \multicolumn{2}{|c|}{ Level ADF statistic } \\
\hline & $\begin{array}{l}\text { Without } \\
\text { Trend }\end{array}$ & $\begin{array}{l}\text { With } \\
\text { Trend }\end{array}$ & $\begin{array}{l}\text { Without } \\
\text { Trend }\end{array}$ & $\begin{array}{l}\text { With } \\
\text { Trend }\end{array}$ \\
\hline GDP & -2.923780 & -3.506374 & -1.701408 & -2.597907 \\
\hline AVA & -2.926622 & -3.504330 & -1.437325 & -3.557177 \\
\hline IVA & -2.922449 & -3.504330 & -1.878993 & -2.140762 \\
\hline K & -2.923780 & -3.506374 & -2.186281 & -2.640403 \\
\hline$M$ & -2.922449 & -3.504330 & -0.897449 & -1.743977 \\
\hline NOX & -2.922449 & -3.504330 & 0.799497 & -1.614126 \\
\hline EXR & -2.923780 & -3.506374 & -0.224720 & -2.235219 \\
\hline
\end{tabular}

Note: ADF shows that there is unit root in the series.

However, as shown in table 2, when the first differences of the variables are considered, the null hypothesis is rejected in favor of alternative hypothesis which state that series are stationary. 
Table 2. ADF Unit Root Test: First difference series

\begin{tabular}{|c|c|c|c|c|}
\hline \multirow[t]{2}{*}{ Variable } & \multicolumn{2}{|c|}{$5 \%$ critical value } & \multicolumn{2}{|c|}{$\begin{array}{l}\text { First Difference } \\
\text { ADF test statistic }\end{array}$} \\
\hline & $\begin{array}{c}\text { Without } \\
\text { Trend }\end{array}$ & $\begin{array}{l}\text { With } \\
\text { Trend }\end{array}$ & $\begin{array}{l}\text { Without } \\
\text { Trend }\end{array}$ & $\begin{array}{l}\text { With } \\
\text { Trend }\end{array}$ \\
\hline GDP & -2.923780 & -3.506374 & -3.820613 & -3.884878 \\
\hline AVA & -2.926622 & -3.504330 & -7.162162 & -7.365388 \\
\hline IVA & -2.922449 & -3.504330 & -5.966275 & -6.094154 \\
\hline K & -2.923780 & -3.506374 & -4.554417 & -4.581873 \\
\hline $\mathrm{M}$ & -2.922449 & -3.504330 & -6.576058 & -6.515266 \\
\hline NOX & -2.922449 & -3.504330 & -7.105603 & -7.421687 \\
\hline EXR & -2.923780 & -3.506374 & -3.484695 & -3.457604 \\
\hline
\end{tabular}

Note: ADF shows the series are stationary.

In second step, we interpret the results of OLS estimates. Ordinary least square approach was applied to the logarithms of the time series employed in this study. The following equation shows the estimated model:
GDP $=3.5500+0.0158 \mathrm{NOX}-0.0839 \mathrm{M}+0.2100 \mathrm{~K}+0.4334 \mathrm{IVA}+0.3413 \mathrm{AVA}$
$\mathrm{t} \quad(6.0975)$
(2.3819)
$(-3.3616)$
(5.6068)
(6.8623)

(3.5663)

-0.1004 EXR - 0.0424DUM 
$(-6.8152)$

$\mathrm{R}^{2}=0.996$

$(-2.1179)$

The estimation has removed autocorrelation problem by using AR (auto-regressive error) and MA (moving average) and all variables except exchange rate were obtained with the expected sign. Variables of non-oil exports (NOX), agricultural value added (AVA), capital formation (K) and industrial value added (IVA) have positive significant impact on economic growth. While, impact of imports (M), exchange rate (EXR) and dummy variable (DUM) have been negative significant. The coefficient size of non-oil exports is about 0.016; in this case one percent change in non-oil exports, other things being equal, will lead to 0.016 percent change in economic growth. It means that due to increase in non-oil exports, economic growth of the country weakly would increase. The positive relationship between non-oil exports and economic growth, found in our study is consistent with the findings of other studies by Mahdavi \& Fatemi (2007) and Mirjamali Mehrabadi et al.(2012). As expected, import has been found significant with negative sign and the coefficient size of imports shows that one percent increase in imports will decrease GDP by 0.08 percent and vice - versa. Taghavi et al. (2012) also found the negative significant relationship between imports and economic growth. Industrial and agricultural value added has been found with positive significant impact on economic growth, which is backed by the study conducted by

Mahdavi \& Javadi (2006). The coefficient size of these variables show that one percent increase in agricultural value added and industrial value added would increase GDP by 0.34 and 0.43 percent respectively. The impact of gross capital formation has been found positive significant which is in conformity with the findings of Komijani and Memarnejad (2004) and Pahlavani (2005). However, the study found the impact of nominal exchange rate on economic growth with unexpected negative sign, and also Khataie \& Gharbali Moghaddam (2005) found increase in nominal exchange rate, has a weak negative impact on GDP growth. The coefficient size of exchange rate is 0.10 ; so one percent increase in exchange rate, would lead to 0.10 percent decrease in economic growth and vice versa.

Further, estimated results reveal that $R^{2}$ is 0.996 ; this implies that 99.6 percent of the total variations in GDP are explained by non-oil exports, imports, exchange rate, industrial value added, agricultural value added, and gross capital formation of the country. This is a very good fit and it shows that a total of $99.6 \%$ systematic variation in the GDP is explained by the variations in the explanatory variables for the period under reviewed (1961-2010). F _statistics is the true explanatory of the goodness of model and it is significant as its $P_{-}$value is 0.000 . Furthermore, the DW statistic suggests that there is no evidence of autocorrelation. 
Table 3: Johansen Co-Integration Test Result

\begin{tabular}{|c|c|c|c|c|}
\hline $\begin{array}{l}\text { Hypothesized } \\
\text { No. of CE(s) }\end{array}$ & Eigen value & Trace Statistic & $5 \%$ Critical Value & Prob.** \\
\hline None* & 0.758749 & 206.7654 & 159.5297 & 0.0000 \\
\hline At most $1^{*}$ & 0.599151 & 138.5133 & 125.6154 & 0.0064 \\
\hline At most 2 & 0.491941 & 94.63315 & 95.75366 & 0.0596 \\
\hline At most 3 & 0.432966 & 62.12957 & 69.81889 & 0.1759 \\
\hline At most 4 & 0.263623 & 34.89742 & 47.85613 & 0.4534 \\
\hline At most 5 & 0.205803 & 20.20877 & 29.79707 & 0.4088 \\
\hline At most 6 & 0.118685 & 9.148436 & 15.49471 & 0.3518 \\
\hline At most 7 & 0.062231 & 3.084097 & 3.841466 & 0.0791 \\
\hline
\end{tabular}

Trace test indicates 2 co-integrating eqn(s) at the 0.05 level.

* denotes rejection of the hypothesis at the 0.05 level.

** MacKinnon-Haug-Michelis (1999) p-values.

Finally, the study applies the Johansen Co-integration test which indicates the number of cointegrating relationships among the variables under consideration. Table 3 shows that at 5\% level of significance, results of trace tests suggest the existence of at least two co-integrating relationships among the variables in the series. In other words, we fail to reject the null hypothesis of no co-integration between research variables; therefore, there is a long run relationship between these variables in Iranian economy for the period of 1961-2010. 


\section{Conclusions and Suggestions}

This research aims to examine the effect of foreign trade on economic growth through empirical analysis using annual data in Iran over the period 1961 to 2010. Results of the model show that all variables have been obtained with expected signs except exchange rate. So, results are mainly satisfactory and signs of the coefficients are supporting the previous research findings. Non-oil exports, gross capital formation, agricultural and industrial value added positively impact on economic growth during the study period. As expected the impact of imports obtained with negative sign, while exchange rate has been found with unexpected negative sign and dummy variable negatively impact on economic growth.

According to the above results, it is suggested that: (i) Imports of intermediate and capital goods can play an important role in the promotion of non-oil exports, therefore their share in total imports should be strengthened, (ii) The government should encourage export diversification and non-oil sector exports should be encouraged; for instance, excise duties should be lowered so as to encourage local industries to export their goods and services (iii) Policy of encouraging the exports in industrial sector should be considered more than agricultural exports, (iv) The business environment should be improved and promote entrepreneurship and productivity, (v) Exchange rate policies can lead to maintain international competitiveness and create sustainable external balance of payments, hence, exchange rate policies should be revised and eliminate exchange rate instability.

\section{References}

Balassa, B. (1978), "Exports and Economic Growth: Further Evidence", Journal of Development Economics, Vol. 5, pp. 181-189.

Balassa, B. (1985), "Exports, Policy Choices, and Economic Growth in Developing Countries after the 1973 Oil Shock", Journal of Development Economics, Vol. 18, pp. 23-35.

Bayoumi, T., Coe, D.T. and Helpman, E. (1999), "Research and Development and Global Growth", Journal of International Economics, Vol. 47, pp. 399-428.

Ben-David, D., Nordstrom, H. and Winters, L.A. (2000), "Trade, Income Disparity, and Poverty", World Trade Organization, Geneva.

Blomstrom, M. and Kokko, A. (2003), "The Economics of Foreign Direct Investment Incentives", NBER Working Paper, No. 9489, National Bureau of Economic Research, Cambridge.

Coe, D.T. and Helpman, E. (1995), "International Research and Development Spillovers", European Economic Review, Vol. 39, pp. 859-887.

Dollar, D. (1992), "Outward-oriented Developing Economies Really do Grow More Rapidly", Economic Development and Cultural Change, Vol. 40 No. 3, pp. 523-544. 
Edwards, S. (1998), “Openness, Productivity and Growth: What do We Really know?" Economic Journal, Vol. 108, pp. 383-398.

Frankel, J.A., Romer, D., (1999) Does trade cause growth? American Economic Review 89, 379399.

Feder, G. (1983), “On Exports and Economic Growth”, Journal of Development Economics, Vol. 12, pp. 59-73.

Goldberg, P. and Pavnik, N. (2007), "Distributional Effects of Globalization in Developing Countries." Journal of Economic Literature 45: 39-82.

Jiles, J. A. and Williams, C. L. $\left(2000_{\mathrm{a}}\right)$, "Export-Led Growth: A Survey of the Empirical Literature and Some Non Causality Results: Part 1." Journal of International Trade and Economic Development 9, 261-337.

Khan, M. and Reinhart, C. (1990). "Private Investment and Economic Growth in Developing Countries", World Development, Vol.18, No.1. Khataie, M. and Gharbali Moghaddam, Y. (2004), "The Dynamic Relationship between Exchange rate and Gross Domestic Product in Economy of Iran", Journal of Budget and Planning, No. 84, 3-25.

Kavoussi, R. M. (1985), "International Trade and Economic Development: The Recent Experience of Developing Countries", Journal of Developing Areas, Vol. 19, pp. 379-392.

Komijani, A. and Memarnejad, A. (2004), "Importance of Quality Manpower in Economic Growth of Iran", Journal of Trade Researches, No. 31.

Krueger, A. (1978), "Foreign Trade Regimes and Economic Development: Liberalization Attempts and Consequences", Ballinger, Cambridge, Massachusetts.

Lall, S. (2000), “Foreign Direct Investment, Technology Development and Competitiveness: Issues and Evidence", Monograph.

Levine R., Renelt, D., (1992), "A sensitivity analysis of cross-country growth", American Economic Review 82, 942-963.

Mahdavi, A and Fatemi, M. (2007), "An Investigation on the Impact of Non- Oil Exports on Economic Growth- Case of Iran", Iranian Economic Review, Vol.12, No.19.

Mahdavi, A and Javadi SH. (2006), "Testing the causal Relationship between Trade and Economic Growth in Iran", Journal of Economic Researches, No. 4, pp.1-20. 
Michaely, M. (1977), "Exports and Growth: An Empirical Investigation", Journal of Development Economics, Vol. 4, pp. 49-53.

Mirjamali Mehrabadi, M. S. Nabiuny, E. and Etemad Moghadam, H. (2012), "Survey of Oil and Non-oil Export Effects on Economic Growth in Iran", Greener Journal of Economics and Accountancy Vol. 1 (1), pp. 008-018, January.

Pahlavani, M. (2005), "The Relationship between Trade and Economic Growth in Iran: An Application of a New Co-integration Technique in the Presence of Structural Breaks", University of Wollongong, Economics Working Paper Series http://www.uow.edu.au/commerce/econ/wpapers.html

Panas, E. and Vamvoukas, G. (2002), "Further evidence on the Export-led Growth Hypothesis" , Applied Economic Letters, 9, 731-5.

Ram, R. (1985), “Exports and Economic Growth: Some Additional Evidence", Economic Development and Cultural Change, Vol. 33, pp. 415-425.

Ram, R. (1987), "Exports and Economic Growth in Developing Countries: Evidence from Time series and Cross Section Data", Economic Development and Cultural Change, Vol. 36, pp. 51-72.

Rodriguez, F., Rodrik, D., (2001), "Trade Policy and Economic Growth: a Skeptics Guide to the Cross-National Evidence", In Bernanke, B., Rogoff, K. S. (Eds.), NBER Macroeconomics Annual 2000, MITPress, Cambridge, Massachusetts.

Taghavi, M. Goudarzi, M. Masoudi, E. Parhizi Gashti, H. (2012), "Study on the Impact of Export and Import on Economic Growth in Iran", Journal of Basic and Applied Scientific Research, 2(12)12787-12794.

Sachs, J. D. (1987), "Trade and Exchange Rate Policies in Growth Oriented Adjustment Programs", in Corbo, V., Goldstein, M. and Khan, M. (Eds.), Growth Oriented Adjustment Programs, IMF, Washington, DC.

Sachs, J.D. (1989), "The Debt Overhang of Developing Countries", in Calvo, G. A. et al (Eds.), Debt, Stabilization and Development: Essays in Memory of Carlos Diaz-Alejandro, Blackwell, Oxford, pp. 80-102.

Singer, H.W. (1950), "The Distribution of Gains between Investing and Borrowing Countries, American Economic Review, Vol. 40, pp. 473-485.

Singer H.W. and Gray, P. (1988), "Trade Policy and Growth of Developing Countries: Some New Data, World Development, Vol. 16, pp. 395-403. 
Tyler, W.G. (1981), "Growth and Export Expansion in Developing Countries: Some Empirical Evidence", Journal of Development Economics, Vol. 9, 121-130.

Te Velde, D.W. (2001), "Government Policies for Inward Foreign Direct Investment in Developing Countries: Implications for Human Capital Formation and Income Inequality, Paper presented at OECD Development Centre conference on FDI and Human Capital.

Wacziarg, R., (2001), "Measuring the Dynamic Gains from Trade”, World Bank Economic Review 15, 393-429. 